\title{
Planting Time and Fertilizer Validation Based on Banyudono Planting Calendar in Boyolali Regency
}

\section{Meinarti Norma Setiapermas, Ridha Nurlaily}

Assesment Institute for Agricultural Technology of Central Java, Tegalsari, Sikunir, Bergas Lor, Semarang, Indonesia 50552

\section{ARTICLE INFO}

\section{Received}

11 March 2020

\section{Revised}

6 August 2020

\section{Accepted for Publication \\ 10 February 2021}

\section{Published}

31 March 2021

doi: 10.29244/j.agromet.35.1.20-29

\section{Correspondence:}

Meinarti Norma Setiapermas

Assesment Institute for Agricultural

Technology of Central Java

Jl. Soekarno - Hatta KM 26 No. 10 Mail

Box 124 Tegalsari, Sikunir, Bergas Lor,

Semarang

Email: meinarti.ns@gmail.com

This is an open-access article

distributed under the CC BY License.

(C)2021 The Authors. Agromet.

\begin{abstract}
A B S T R A C T
Nowadays, information technology on planting calendar and fertilizer dosage remains research challenges, in Indonesia, especially for end user farmers. Integration of the planting calendar (then called as KATAM - 'Kalender Tanam'), has raised many benefits for users since it provides the basic recommendations for seed and fertilizer needs. This research aims to validate the benefit of using Integrated KATAM as guidance for rice planting and fertilizing in Bangak Village, Banyudono Sub-district, with an area of around 6,100 $\mathrm{m}^{2}$. Two different approaches was performed: (i) interviewing farmers about planting date, variety, growth phase, water resource, and their technology to anticipate climate change, and (ii) calculating the rice productivity under different planting date, planting pattern, fertilizer dosage, and variety. Two treatments were used simultaneously on the field within the same planting calendar based on KATAM. The first treatment was a combination of planting date and fertilizer dosage for Situ Bagendit variety, while the second was two fertilizer dosages applied on two rice varieties (Ciherang and Situ Bagendit). Field activity was held on May-August and June-September 2016. The results found that around $60 \%$ of the farmers in Banyudono Sub-district did not applied the integrated KATAM recommendation on planting time. During a year of validation period (2016), 80\% of the farmers applied the rice-rice-rice pattern, and the remaining applied rice-ricepalawija. Our findings revealed that most farmers preferred to use Situ Bagendit variety as its higher tolerance to drought and higher potential yield. By applying KATAM recommendation, Situ Bagendit rice variety gave the highest productivity up to 8.89 ton/ha compared to other rice varieties. Further the research highlights the use of KATAM recommendation may increase rice productivity especially when Situ Bagendit is applied.
\end{abstract}

\section{KEYWORDS}

Duncan's Multiple Range Test, rice variety, rice productivity, Situ Bagendit, yield component

\section{INTRODUCTION}

Providing farmers with advanced tools and knowledge to implement sustainable production is one of the essential efforts to mitigate the impacts of climate change on the agricultural sector. Several actions to achieve this effort is by providing droughttolerant varieties (Loboguerrero et al., 2019; Mottaleb et al., 2017; Perdinan et al., 2008; Yasin and Ma'shum, 2006), high-temperature tolerant varieties (Killi et al., 2017), and saline tolerant varieties (Thi Nhung et al., 2019); improving forestry agriculture (Shrestha et al., 2018); enriching biodiversity (Thierfelder et al., 2017); optimizing the efficient use of rainwater (Setiapermas and Jauhari, 2008; Srihartanto and Widodo, 2020;
Velasco-Muñoz et al., 2019); replenishing groundwater with conservation agriculture (Lillo et al., 2019); developing marine defense systems (Koh and Teh, 2020); and better floods management in situations of sea-level rise and storm surges (Lilai et al., 2016). All these actions are beneficial to improve mitigation of the impacts of current extreme climate variability, as well as countering the adverse effects of climate change in the future (Bruinsma, 2003).

One of the Ministry of Agriculture's strategic programs is to increase the production of rice, corn, and soybeans (Fudjaja et al., 2020; Juhandi et al., 2018). A few problems in implementing the program are the lack of supporting facilities and the farmers' lack of 
knowledge about location-specific technologies (irrigated rice fields, rainfed rice field, dry land, or suboptimal land), lack of knowledge and application of pest and disease control according to field conditions, and the application of technological innovation is not yet fully aimed to anticipate climate change impacts (drought or inundation) (Aslam, 2016; Estiningtyas and Rahman, 2020). The innovation of information technology of the planting calendar (integrated KATAM) on food crops which has been published by the Agricultural Research and Development Agency in anticipation of extreme climate is the basic reference for irrigation, seed requirements, variety needs, and fertilizer dosages for extension workers and farmers. Unfortunately, the utilization of this integrated KATAM technology by new extension workers and farmers at this moment is limited only as a reference of fertilizer demand information for fertilizer subsidy.

The availability of information about climate and agricultural cultivation technology in facing extreme climate will greatly help in planning the farming strategies at the user level. Prediction of planting time is very important for policymakers, extension workers, and farmers to plan cultivation practices such as commodity and variety selection, irrigation planning, fertilizer dosages, and other agricultural aspects. For policymakers, predicting planting time is required to plan the strategies to distribute seed and fertilizer.

Prediction of agricultural yield is also needed to find out areas that experience a surplus or deficit, thus it can be further used to develop strategies in agricultural production distribution and stocks. For extension workers, this information is used as a base in providing recommendations on planting time with better results to farmers. Furthermore, farmers' ability to adapt effectively by utilizing climate predictions can affect the national economy, especially in countries that highly dependent on the agricultural sector. The purpose of this study is to obtain verification and validation data of integrated planting calendar (KATAM) on rice fields including planting time, crop varieties, farmers' technology for anticipating climate change, also water resource data for irrigated and rainfed rice fields.

\section{RESEARCH METHODS}

The validation activity was carried out in Bangak Village, Banyudono Sub-district, Boyolali Regency in the dry season of 2015/2016, and the research area was the technical irrigation rice field of Gisik Dam located in Banyudono Sub-district, Boyolali Regency (Figure 1). Two of the required research materials were the planting calendar map of Boyolali Regency in the dry season of 2015/2016 and input of rice production facilities. This study compared the information of integrated KATAM with observation data and validated the available information in integrated KATAM by util izing some information of the production input which is adjusted to the integrated planting calendar map (integrated KATAM).

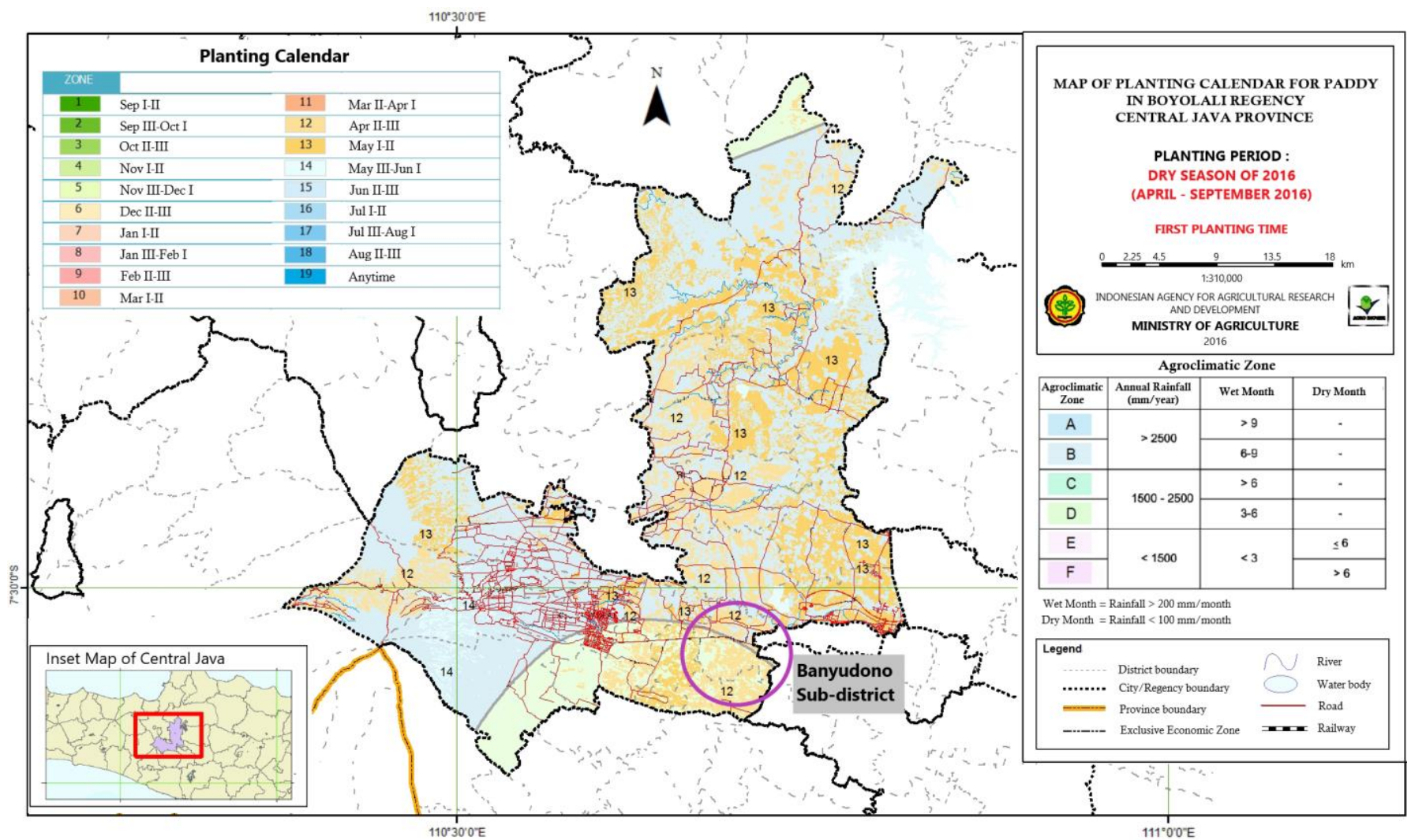

Figure 1. Planting calendar map of Banyudono Sub-district, Boyolali Regency, in the dry season of 2016. 
Information on planting time recommended by integrated KATAM is the $2^{\text {nd }}$ to $3^{\text {rd }}$ week of April (11-30 April 2016), while validation of planting time was carried out before the recommendation of integrated KATAM. The first period of validation was performed from 27 May (planting) to 27 August 2016 (harvest) with an area of $6,000 \mathrm{~m}^{2}$, and the second was from 14 June (planting) to 14 September 2016 (harvesting) with an area of $5,200 \mathrm{~m}^{2}$. In addition to planting time, another treatment implemented was two fertilizer dosage recommendations. The first was KATAM recommend-ation (Phonska $350 \mathrm{~kg} / \mathrm{ha}$ and urea 200 $\mathrm{kg} / \mathrm{ha}$ ) and the second was farmers' fertilizer dosage routine (Phonska $600 \mathrm{~kg} / \mathrm{ha}, 200 \mathrm{~kg} / \mathrm{ha}$ urea, and 285 $\mathrm{kg} / \mathrm{ha}$ SP-36). The varieties planted were Situ Bagendit and Ciherang. The planting plot of Situ Bagendit and Ciherang rice varieties planted on 27 May 2016 had an area of $6,000 \mathrm{~m}^{2}$ while the planting plot of Situ Bagendit rice varieties on 14 June 2016 had an area of 5,200 $\mathrm{m}^{2}$.

The data obtained were productivity, percentage of filled grain, 1,000 grains of grain weight, the maximum number of tillers, root length, and panicle length. Data were analyzed by Duncan's Multiple Range Test $5 \%$ method which compared the yield of the two planting seasons for the Situ Bagendit variety (planting time in April and planting in May) as well as the agronomic data between each treatment for each planting season. Social data on the utilization of irrigation networks were taken by focused interviews on members of farmer groups. The collection was carried out with a farmer group meeting in Bangak Village. The question materials are the area of paddy fields and rice productivity at the same planting time.

\section{RESULTS AND DISCUSSIONS}

Map of the planting calendar (KATAM) which is recommended by the Agroclimate Research and Hydrology Center, Center for Agricultural Land Resources, Agricultural Research and Development Agency of the Ministry of Agriculture in the dry season of 2015/2016 is the basis of consideration for the users of irrigated rice field cultivation technology. An integrated planting calendar is a tool that provides spatial and tabular information about predictions of the planting season, cropping patterns, potential planting areas, areas prone to flood and drought, attacks by pests, recommended varieties, the rice and secondary crops needs, recommended fertilizer dosage and requirements, and also agricultural machinery or tools (alsintan) recommendations based on predictions of climate change and variability.

This integrated planting calendar can be used to determine the planting time of each season (rainy season and dry season), to determine cropping patterns and crop rotation, to estimate the potential planting area in crop planning and food crop production, also to predict the decrease or failure in production and farmers' losses due to drought, flooding, or attack by pests (Anggarendra et al., 2016; Fahri et al., 2019). Several accessible information from the KATAM calendar are planting time, fertilizer dosage, varieties, and pest attacks which usually occurred at the sub-district level. Boyolali Regency is one of the riceproducing areas in Central Java with a total rice field area of about 22,710 ha.

The sources of irrigation water in Boyolali Regency are dams (weirs), trench dams, and reservoirs (springs whose water is collected in the form of ponds). Farmers, especially those who plant rice commodities in Boyolali Regency performed adaptation efforts to climate change which is modified to the conditions of the irrigation network. Rivers that are the source of irrigation water in Boyolali Regency are Pepe River, Serang River, Cemara River, Butak River, and Gandul River. Banyudono Sub-district in Boyolali Regency is an area of irrigated rice fields whose water sources come from the Pepe River and the Pengging spring (Figure 2). At this location, there are also Drono Dam, Karangkulon Dam, Gisik Dam, and Bukur Ireng Dam for rice field irrigation. The main source for irrigation in Bangak Village comes from Gisik Dam. Rainfall condition at the planting time after KATAM recommendation indicated that at that time it was approaching the dry season.

Banyudono sub-district has a rice field area of about 1,515 ha (BPS, 2016a). However, rice fields that can be irrigated in planting season III from the irrigation network were around 1,300 ha. Bangak Village in Banyudono Sub-district, Boyolali Regency has a total of technical irrigated rice fields area about 75 ha. Irrigation water availability in this region is sufficient and allows farmers to grow rice continuously in one year (with a rice-rice-rice planting pattern). However, in a long dry season, some farmers preferred corn to be planted in the planting season III since the irrigation water was not accessible in the rice fields location.

According to interview results with the Head of Gapoktan in Bangak Village, one of the efforts to expand the area of rice fields that can be irrigated during planting season III is repairing the primary channels in dams and maintaining the secondary channels in irrigation networks. Another problem faced by farmer groups is the silting of Pepe River around Gisik Dam. Therefore, each group performed sediments and rubbish dredging manually every dry season. Rainfall data in Boyolali Regency is listed in Table 1.

The recommended planting season III in 2015/2016 by integrated KATAM for Banyudono Subdistrict is on the $2^{\text {nd }}$ to $3^{\text {rd }}$ week of April. However, due 
Table 1. Amount of rainfall and number of rainy days by month in Boyolali Regency, 2016.

\begin{tabular}{lcc}
\hline Month & Rainfall (mm) & Rainy Days \\
\hline January & 400 & 21 \\
\hline February & 356 & 20 \\
\hline March & 351 & 19 \\
\hline April & 269 & 14 \\
\hline May & 230 & 16 \\
\hline June & 130 & 11 \\
\hline July & 124 & 13 \\
\hline August & 147 & 13 \\
\hline September & 222 & 14 \\
\hline October & 273 & 16 \\
\hline November & 288 & 15 \\
\hline December & 375 & 17 \\
\hline
\end{tabular}

Source: (BPS, 2016b)

to the availability of sufficient water every year, farmers did not plant in unison. Results from interviews and surveys showed that farmers who plant rice in accordance with integrated KATAM occupied only $40 \%$ of the total irrigated rice field area of Banyudono Subdistrict. As much as $80 \%$ of the total respondents in the Ba-nyudono sub-district applied the rice-rice-rice planting pattern and the remaining 20\% applied the rice-rice-palawija (corn) pattern.

The application of planting patterns in a rice field area is influenced by the availability of water, irrigation network facilities, and cli mate anomalies. The climate anomaly that often occurs is El Niño which causing limited irrigation water (Mursidi and Sari, 2017). In determining the planting season, part of the Boyolali region adheres to the principles of local wisdom, namely pranoto mongso, by reading natural phenomenons such as falling leaves, flying kapok randu, tubers growth, etc.

The management of water in each area that uses irrigation channels was helped by an officer of the farmer groups who is assigned to create a schedule for the irrigation distribution between blocks, especially if there is water scarcity. Farmer group institutions have been running well, as evidenced by the existence of an orderly recorded administration and regular meetings. Types of activities that are usually coordinated by farmer groups are pest control, irrigation channel maintenance, and irrigation arrangements.

In a long dry season, where the water discharge is receding in some places, rice is not planted, then farmers tend to cultivate crops to minimize crop failure due to the lack of water. Based on interview results, the 2015/2016 rainy season began in October and ended in April, and the dry season started in May. The beginning of the rainy season was followed by farmers' planting season. The dominant rice varieties cultivated by farmers in the planting season I was IR 64 for about $80 \%$ of the total farmers, and in the planting seasons II and III was Situ Bagendit which preferred by around $80 \%$ and $75 \%$ of the total farmers (Table 2). Situ Bagendit variety was considered better in planting season II and III because the variety has a higher yield and more resistance to drought.

As an effort of climate change adaptation in several points in Bangak Village, Banyudono Subdistrict, Boyolali Regency, there was also corn cultivation during planting season III. According to the interviewees, the cultivation was carried out on an average of 0.2 ha of land. The variety planted is Pertiwi which includes hybrid maize, and the farmers were required to purchase new seeds for every cultivation.
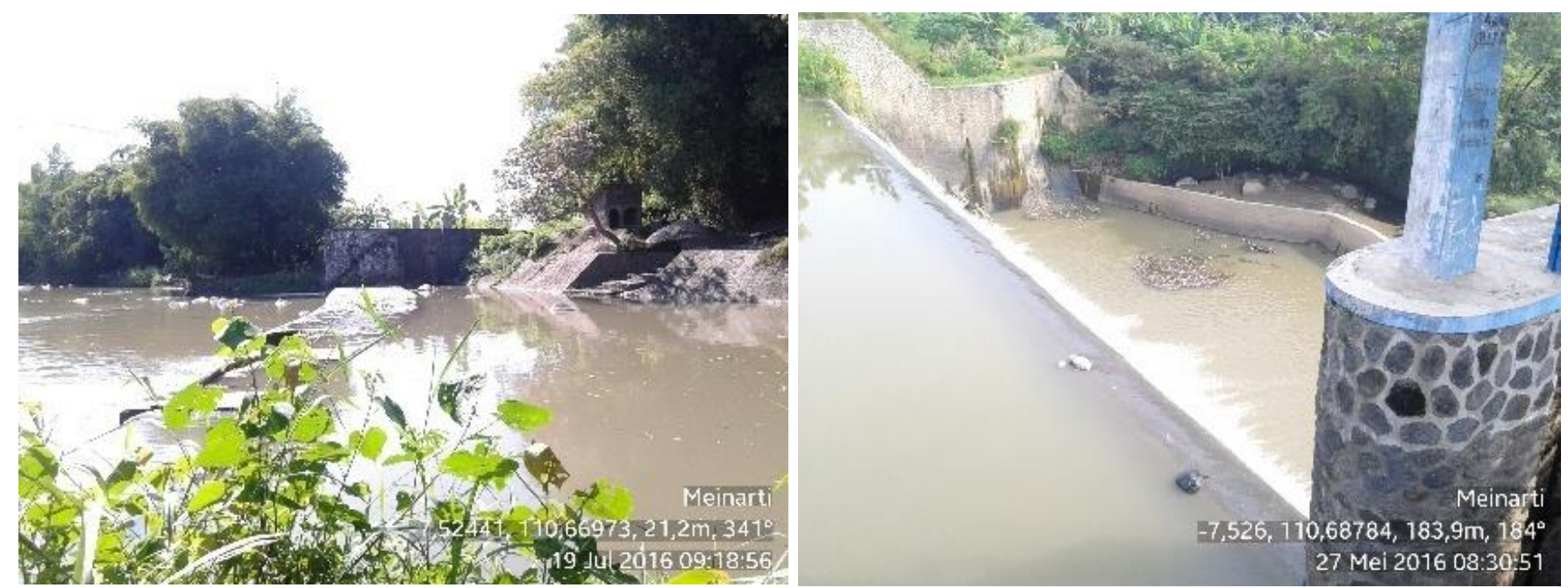

Figure 2. Drono and Gisik Dam in Pepe River, Banyudono sub-district, as the main source of rice fields irrigation. 
Table 2. Rice varieties, which were commonly planted in Bangak Village, Banyudono Sub-district, for each planting season.

\begin{tabular}{cc}
\hline Rice Varieties & $\begin{array}{c}\text { Number of farmers } \\
\text { used (\%) }\end{array}$ \\
\hline Planting Season I & \\
\hline a. IR 64 & 80,00 \\
b. Ciherang & 10,00 \\
c. Memberamo & 10,00 \\
\hline Planting Season II & \\
\hline a. IR 64 & 10,00 \\
b. Memberamo & 10,00 \\
c. Situ Bagendit & 80,00 \\
\hline Planting Season III & \\
\hline a. Situ Bagendit & 75,00 \\
b. IR 64 & 25,00 \\
\hline
\end{tabular}

The productivity gained reached 6.5 tons/ha. This result can be optimized by adding supplementary inputs for fertilizer to get close to the potential productivity for maize which is around 8 tons/ha. Apart from the planting patterns that were adjusted to the local climate and agroecosystem, farmers in Bangak Village of Banyudono Sub-district also adapted to the availability of irrigation water in each planting season. The adaptation performed by farmers was irrigating inter-mittently in the planting season II and III.

The validation of planting time and recommended fertilizer dosage of integrated KATAM depend on the availability of irrigation water, far-mers' readiness, and farmers' habits at the field level. The validation of planting time was carried out after the integrated KATAM recommendations, which was on 27 May 2016 and 14 June 2016. The results of the validation showed that the most profitable planting time for the Banyudono subdistrict was after the recommendation of integrated KATAM. Results from field observations and validations about the productivity comparison of rice which was planted for each planting time is depicted in Table 3 . Table 3 shows that the productivity of rice with planting time after KATAM recommendation (5.6 tons milled dry grain/ha) was higher than those before the recommendation of KATAM (3.2 tons milled dry grain/ha). This is due to the availability of sufficient water in the planting season III. Membramo rice variety has a potential yield of 6.5 tons/ha (BPPP, 2019a) while Situ Bagendit variety has a potential yield of 5 tons/ha (BPPP, 2019b).

The observation results of the agronomic component and the yield component in the assessment plot (planting time after the recommendation of integrated KATAM) are depicted in Table 3, Table 4, and Table 5. Table 3 shows that some agronomic components such as the maximum number of tillers and productive tillers (15 stems and 18 stems), also the length of root and panicle at both planting season II and III were not significantly different. The time difference in planting time for Situ Bagendit variety was about 18 days ( 2 dasarian). Table 3 also shows that only the number of empty clumps is significantly different between the two planting seasons. Therefore, we suggest that planting in June to September 2016 was risky. This was also because of the golden snail attack. The maximum number of tillers, number of productive tillers, root length, and panicle length for each treatment were also not significantly different.

According to Table 4, the highest number of tillers, the highest number of productive tillers and maximum length of panicle were attained in planting time June with fertilizer dosage following KATAM recommendation and the results were not significantly different from other treatments. The highest number of empty clumps were attained in planting time May with fertilizer dosage following farmers recommendation and the result also has no significant difference with the other treatment in the same planting time. However, it was significantly different from the results in planting time June for both fertilizer dosages.

Table 3. Rice productivity comparison (tons milled dry grain/ha) according to planting time in Bangak Village, Banyudono Sub-district, in planting season II and planting season III of 2015/2016.

\begin{tabular}{|c|c|c|c|c|c|}
\hline Location & \multicolumn{2}{|c|}{ Starting of Planting Time } & $\begin{array}{c}\text { Percentage Area } \\
\text { of } 1500 \text { ha }\end{array}$ & Varieties & $\begin{array}{l}\text { Productivity (ton } \\
\text { milled grain/ha) }\end{array}$ \\
\hline \multirow{5}{*}{$\begin{array}{l}\text { Bangak } \\
\text { Village, } \\
\text { Banyudono } \\
\text { Sub-district }\end{array}$} & $\begin{array}{l}\text { Planting time } \\
\text { in accordance } \\
\text { with KATAM }\end{array}$ & $\begin{array}{l}2^{\text {nd }}-3^{\text {rd }} \text { week of } \\
\text { April, } 12 \text { April }\end{array}$ & $42 \%$ & Membramo & 3.5 \\
\hline & $\begin{array}{l}\text { Planting time } \\
\text { before KATAM }\end{array}$ & 7 March & $42 \%$ & Situ Bagendit & 3.2 \\
\hline & \multirow{3}{*}{$\begin{array}{l}\text { Planting time } \\
\text { after KATAM }\end{array}$} & \multirow{2}{*}{27 May } & \multirow{2}{*}{$15 \%$} & Situ Bagendit & 5.2 \\
\hline & & & & Ciherang & 4.4 \\
\hline & & 14 June & $1 \%$ & Situ Bagendit & 6.1 \\
\hline
\end{tabular}


The maximum length of the root was attained in planting time May with fertilizer dosage following KATAM recommend-dation and has no significant difference from other treatments. Table 4 shows that the highest productivity and number of empty grains were attained in the planting time June with fertilizer dosage following KATAM recommendation and the result was not significantly different from other treatments. The maximum amount of filled grain and highest average filled grain were attained in planting time May with fertilizer dosage following farmers recommendation and the result also was not significantly different from other treatments. Not far different from the previous result.

Table 5 shows that the highest gross weight of grain, dry weight of grain, and grain weight of 1000 grains in planting time June with fertilizer dosage following KATAM recommendation and the result was not significantly different from other treatments. The result of observation performed in Bangak Village, Banyudono Sub-District during the 2015/2016 dry season was corresponding to a study submitted by Satoto et al., (2013). Satoto et al., (2013) revealed that the yield from IR 64 variety planted during two planting seasons in Central and West Java in 2001-2003 had a difference of 3.8 tons/ha when planted in the 2001 dry season, whereas the difference in the 2002 wet season was only 1.6 tons/ha. They also added that cultivation in the dry season and wet season in 2010 resulted in yield differences and there were interactions between genotypes and planting season in testing 29 ultra-early accessions of rice gross weight germplasm collection in Kuningan (altitude $\pm 600 \mathrm{~m}$ ). Thus, Satoto et al., (2013) stated that the tested genotypes had differing reactions toward the seasonal changes.

Several attempts can be performed to lower the gaps in inter-season yield. The first thing which can be performed is to identify the dominating biota that constructs the irrigated rice field habitat in the dry and wet season. This is mainly to find out the differing prevalence of pests and insects, the presence of pathogens causing plant diseases, and natural weeds that can be utilized to overcome pest attack and disease. The observation results showed that there is a connection between climate change attributes, such as increasing temperature, with the spread of pests and plant diseases. When the increasing temperature is accompanied by increasing humidity, the number of pests population, pests attacks, and plant diseases also tend to increase. The application of season-specific cultivation techniques plays a major role in minimizing the gaps in inter-season yield.

Table 4. Rice productivity comparison for planting time in May-August (W1) and June-September (W2) 2016 in Bangak Village, Banyudono Sub-district, Boyolali Regency.

\begin{tabular}{ccccccccc}
\hline Treatments & $\begin{array}{c}\text { Maximum } \\
\text { number of } \\
\text { tillers }\end{array}$ & $\begin{array}{c}\text { Number of } \\
\text { productive } \\
\text { tillers }\end{array}$ & $\begin{array}{c}\text { Number } \\
\text { of empty } \\
\text { clumps }\end{array}$ & $\begin{array}{c}\text { Length of } \\
\text { root } \mathbf{( c m})\end{array}$ & $\begin{array}{c}\text { Length of } \\
\text { panicle } \\
(\mathbf{c m})\end{array}$ & $\begin{array}{c}\text { Grain } \\
\text { Moisture } \\
\text { Level }\end{array}$ & $\begin{array}{c}\text { Number of } \\
\text { empty } \\
\text { grain }\end{array}$ & $\begin{array}{c}\text { \% Filled } \\
\text { Grain }\end{array}$ \\
\hline W1P1 & $22.03^{\mathrm{a}}$ & $15.67^{\mathrm{a}}$ & $14.67^{\mathrm{a}}$ & $21.27^{\mathrm{a}}$ & $24.00^{\mathrm{a}}$ & $31.62^{\mathrm{a}}$ & $15.67^{\mathrm{a}}$ & $0.91^{\mathrm{a}}$ \\
\hline $\mathrm{W} 1 \mathrm{P} 2$ & $19.77^{\mathrm{a}}$ & $15.00^{\mathrm{a}}$ & $10.33^{\mathrm{ab}}$ & $21.87^{\mathrm{a}}$ & $25.00^{\mathrm{a}}$ & $29.74^{\mathrm{a}}$ & $15.33^{\mathrm{a}}$ & $0.90^{\mathrm{ab}}$ \\
\hline $\mathrm{W} 2 \mathrm{P} 1$ & $19.13^{\mathrm{a}}$ & $17.57^{\mathrm{a}}$ & $0.67^{\mathrm{bc}}$ & $19.53^{\mathrm{a}}$ & $25.67^{\mathrm{a}}$ & $27.46^{\mathrm{a}}$ & $16.37^{\mathrm{a}}$ & $0.88^{\mathrm{b}}$ \\
\hline $\mathrm{W} 2 \mathrm{P} 2$ & $22.67^{\mathrm{a}}$ & $19.17^{\mathrm{a}}$ & $0.00^{\mathrm{c}}$ & $21.27^{\mathrm{a}}$ & $26.20^{\mathrm{a}}$ & $27.28^{\mathrm{a}}$ & $17.37^{\mathrm{a}}$ & $0.88^{\mathrm{b}}$ \\
\hline Sig. & 0.210 & 0.056 & & 0.174 & 0.074 & 0.58 & 0.244 & \\
\hline
\end{tabular}

\begin{tabular}{cccccccc}
\hline Treatments & $\begin{array}{c}\text { Rice yield } \\
\text { per Ubinan* } \\
(\mathbf{k g})\end{array}$ & $\begin{array}{c}\text { Rice } \\
\text { productivity } \\
\text { (kg/ha) }\end{array}$ & $\begin{array}{c}\text { Average } \\
\text { of filled } \\
\text { grain }\end{array}$ & $\begin{array}{c}\text { Number } \\
\text { of filled } \\
\text { grain }\end{array}$ & $\begin{array}{c}\text { Gross } \\
\text { Weight of } \\
\text { Grain (gr) }\end{array}$ & $\begin{array}{c}\text { Dry } \\
\text { Weight of } \\
\text { Grain (gr) }\end{array}$ & $\begin{array}{c}\text { Weight of } \\
\mathbf{1 , 0 0 0} \\
\text { grains (gr) }\end{array}$ \\
\hline W1P1 & $5.21^{\mathrm{a}}$ & $7578.20^{\mathrm{a}}$ & $161.67^{\mathrm{a}}$ & $1616.00^{\mathrm{a}}$ & $41.33^{\mathrm{a}}$ & $36.33^{\mathrm{a}}$ & $22.45^{\mathrm{a}}$ \\
\hline W1P2 & $5.19^{\mathrm{a}}$ & $7544.20^{\mathrm{a}}$ & $145.00^{\mathrm{b}}$ & $1209.30^{\mathrm{b}}$ & $40.33^{\mathrm{a}}$ & $33.67^{\mathrm{a}}$ & $28.91^{\mathrm{a}}$ \\
\hline W2P1 & $6.02^{\mathrm{a}}$ & $8756.40^{\mathrm{a}}$ & $126.97^{\mathrm{c}}$ & $1269.70^{\mathrm{b}}$ & $44.00^{\mathrm{a}}$ & $36.67^{\mathrm{a}}$ & $28.88^{\mathrm{a}}$ \\
\hline W2P2 & $6.11^{\mathrm{a}}$ & $8892.10^{\mathrm{a}}$ & $126.70^{\mathrm{c}}$ & $1267.00^{\mathrm{b}}$ & $45.33^{\mathrm{a}}$ & $39.00^{\mathrm{a}}$ & $31.00^{\mathrm{a}}$ \\
\hline Sig. & 0.55 & 0.55 & & & 0.164 & 0.116 & 0.55 \\
\hline
\end{tabular}

Note: * Ubinan is a term for a rice harvest measurement tools; W1 showed the planting time in May while W2 showed planting time in June; P1 showed farmers' fertilizer dosage while P2 showed KATAM's fertilizer dosage; $a, a b, b c$, and $c$ are the ranking code for the average value of treatment consecutively from largest to smallest which used to determine the difference in effect between treatments by Duncan's Multiple Test Results (DMRT). Numbers in the same column followed by the same letter shows no significant difference in the DMRT test level of $5 \%$. 
Currently, farmers are still implementing the same rice cultivation system in both the wet season and dry season although the agroclimatic differences in those seasons affect the agronomical and physiological growth of the rice plants. Therefore, fertilizer dosage recommendation, spacing, irrigation systems, pest control, and other cultivation techniques are needed to be differentiated between the wet season and the dry season. Appropriate application of season-specific technology will minimize the inter-season yield gaps which then lead to an increased rice production and national food security (Espe et al., 2016). Adoption of technology through a comprehensive approach is also recommended so that the season-specific technology already existing can be implemented on farmers' land.

The yield gaps occur because of different techniques between one and other farmers, different seasons, and different locations is still relatively large, thus technology adoption is expected to increase rice productivity in farmers' fields (Nakano et al., 2018). The next essential supporting factor is weather forecasting based on the season. The forecasting result is required to be the basis in determining the start of planting time and the technology to be applied in each season.

Yang et al., (2008) stated that rice yield varies depending on the planting season in tropical irrigation conditions. The rice yield in the dry season is higher than in the rainy season (Wang et al., 2016) because the amount of solar radiation received during the grain ripening stage is higher in the dry season. Likewise, the accumulation of biomass from flowering to physiological maturity occurs faster in the dry season rather than the rainy season, but there is no translocation of accumulated biomass before flowering into pulp. The total aboveground biomass during physiological maturation is an important factor to evaluate the yield gap between the dry and wet seasons. In addition, average daily solar radiation, biomass accumulation during the ripening stage, and declining production efficiency per unit of biomass are also other important factors in evaluating the yield gap between the dry and wet seasons under tropical irrigated conditions.

The results from observations on Situ Bagendit and Ciherang varieties cultivation (May-August 2016) showed that Situ Bagendit was the more suitable variety to be planted in the dry season with very limited irrigation. Table 5 shows that the highest number of productive tillers in Situ Bagendit variety was attained with fertilizer dosage following KATAM recommendation, even though the result was not significantly different from other treatments. According to Table 5, the highest productivity was attained in Situ Bagendit variety with fertilizer dosage following farmers' recommendation. However, the result also was not significantly different from one another. This indicated

Table 5. Comparison analysis of agronomic components and yield of Situ Bagendit and Ciherang rice varieties in planting time of May-August 2016.

\begin{tabular}{llllllll}
\hline $\begin{array}{l}\text { Treatments (fertilizer } \\
\text { dosage-rice varieties) }\end{array}$ & $\begin{array}{c}\text { Maximum } \\
\text { number of } \\
\text { tillers }\end{array}$ & $\begin{array}{c}\text { Number of } \\
\text { productive } \\
\text { tillers }\end{array}$ & $\begin{array}{c}\text { Length } \\
\text { of } \\
\text { panicle } \\
\text { (cm) }\end{array}$ & $\begin{array}{c}\text { Length } \\
\text { of root } \\
\mathbf{( c m})\end{array}$ & $\begin{array}{c}\text { Number of } \\
\text { empty } \\
\text { clumps }\end{array}$ & $\begin{array}{c}\text { Average } \\
\text { of filled } \\
\text { grain }\end{array}$ & $\begin{array}{c}\text { Average } \\
\text { of empty } \\
\text { grain }\end{array}$ \\
\hline Farmer's-Ciherang & $16.25^{\mathrm{bc}}$ & $13.00^{\mathrm{a}}$ & $22.95^{\mathrm{b}}$ & $18.40^{\mathrm{b}}$ & $6.50^{\mathrm{a}}$ & $153.85^{\mathrm{bc}}$ & $13.35^{\mathrm{b}}$ \\
\hline Farmer's-Situbagendit & $22.16^{\mathrm{a}}$ & $15.36^{\mathrm{a}}$ & $24.26^{\mathrm{a}}$ & $21.26^{\mathrm{a}}$ & $14.67^{\mathrm{a}}$ & $161.60^{\mathrm{ab}}$ & $15.60^{\mathrm{a}}$ \\
\hline Katam-Ciherang & $15.50^{\mathrm{c}}$ & $13.65^{\mathrm{a}}$ & $24.55^{\mathrm{a}}$ & $21.30^{\mathrm{a}}$ & $6.50^{\mathrm{a}}$ & $166.85^{\mathrm{a}}$ & $17.05^{\mathrm{a}}$ \\
\hline Katam-Situbagendit & $19.68^{\mathrm{ab}}$ & $15.48^{\mathrm{a}}$ & $25.04^{\mathrm{a}}$ & $21.86^{\mathrm{a}}$ & $10.33^{\mathrm{a}}$ & $144.72^{\mathrm{c}}$ & $15.52^{\mathrm{a}}$ \\
\hline
\end{tabular}

\begin{tabular}{|c|c|c|c|c|c|c|c|c|}
\hline $\begin{array}{l}\text { Treatments (fertilizer } \\
\text { dosage-rice varieties) }\end{array}$ & $\begin{array}{c}\text { Grain } \\
\text { moist- } \\
\text { ure } \\
\text { level }\end{array}$ & $\begin{array}{l}\text { Rice } \\
\text { yield } \\
\text { per } \\
\text { Ubinan* } \\
\text { (kg) }\end{array}$ & $\begin{array}{c}\text { Producti } \\
\text {-vity } \\
\text { (kg/ha) }\end{array}$ & $\begin{array}{c}\text { Gross } \\
\text { Weight } \\
\text { of Grain } \\
\text { (gr) }\end{array}$ & $\begin{array}{c}\text { Dry } \\
\text { Weight } \\
\text { of } \\
\text { Grain } \\
\text { (gr) }\end{array}$ & $\begin{array}{c}\text { The } \\
\text { number } \\
\text { of filled } \\
\text { grains is } \\
10 \\
\text { clumps }\end{array}$ & $\begin{array}{c}\text { Weight } \\
\text { of } \\
1,000 \\
\text { grains } \\
\text { (gr) }\end{array}$ & $\begin{array}{c}\text { Percent } \\
\text { of filled } \\
\text { grain } \\
(\%)\end{array}$ \\
\hline Farmer's-Ciherang & $24.68^{b}$ & $4.105^{\mathrm{a}}$ & $5,979.9^{a}$ & $38.50^{\mathrm{a}}$ & $31.00^{\mathrm{a}}$ & $1,538.5^{a b}$ & $20.185^{a}$ & $0.92^{a}$ \\
\hline Farmer's-Situbagendit & $31.62^{a}$ & $5.210^{a}$ & $7,578.2^{a}$ & $41.33^{a}$ & $36.33^{a}$ & $1,616.0^{a}$ & $22.450^{a}$ & $0.91^{a b}$ \\
\hline Katam-Ciherang & $30.13^{a}$ & $4.575^{a}$ & $6,654.5^{a}$ & $44.00^{a}$ & $39.00^{a}$ & $1,731.0^{a}$ & $22.525^{\mathrm{a}}$ & $0.91^{\mathrm{ab}}$ \\
\hline Katam-Situbagendit & $29.74^{a}$ & $5.186^{a}$ & $7,544.2^{a}$ & $40.33^{a}$ & $33.67^{a}$ & $1,209.3^{b}$ & $28.903^{a}$ & $0.90^{\mathrm{b}}$ \\
\hline
\end{tabular}

Note: $a, a b, b c$, and $c$ are the ranking code for the average value of treatment consecutively from largest to smallest which used to determine the difference in effect between treatments by Duncan's Multiple Test Results (DMRT). Numbers in the same column followed by the same letter shows no significant difference in the DMRT test level of $5 \%$. 
that the use of a very high fertilizer dosage from farmers' recommendation resulted in an insignificant difference of yield with other treatments which followed KATAM recommendation. Thus, at the September meeting, cooperative farmers would switch to follow the KATAM fertilizer dosage recommendation with Situ Bagendit variety.

According to Sution et al., (2019), the productivity of highland rice planted in the 2016/2017 dry season and 2017/2018 rainy season in Sanggau Regency, West Kalimantan is significantly influenced by planting time. The productivity of highland rice in Batu Tegi (6.20 tons/ha), Inpago 8 (5.87 tons/ha), and Situ Bagendit (4.66 tons/ha) were higher when planted in the dry season than in the rainy season. Koesrini et al., (2019) proposed that there were differences in yield between rice varieties planted in the dry season (March to July 2018) and the rainy season (October 2018 to February 2019) on swampland. The highest yield was achieved by the Inpara- 1 variety with 6.6 tons/ha, while the yield of other varieties (Inpara 2, Inpara 3, Inpara 4, Inpara 6, Inpara 8, Inpara 9, and Inpari 32) ranged from 3.98 to 5.90 tons/ha. The yield of un-hulled rice in the rainy season was $89.4 \%$ higher than the dry season.

Extension workers, pest observers, and production input distributors play a major role in addressing the implementation of climate change adaptation technology in irrigated rice fields. One component of the technology of climate change adaptation needed by farmers is the use of droughttolerant varieties such as Situ Bagendit, Inpari 38, or Inpari 41. Among three rice varieties that survived at the farmers' level, IR 64 was the most adaptive variety in every condition of the agroecosystem. IR 64 is a variety released by the government around the 1970s and the field instructors are recommended to replace this variety with Situ Bagendit or Mekongga.

In rainfed rice fields, farmers preferred Sunggal and Pepe varieties. The majority of Banyudono farmers applied the rice-rice-rice planting pattern with Situ Bagendit variety in both planting seasons. The remaining farmers decided to plant Ciherang, Mekongga, or Mentik Wangi (a local variety that is fluffier) variety. Prediction of rice productivity at various planting dates provides information on planting time intervals with the highest potential productivity. If the delay in planting time is unavoidable, farmers can prepare the technological inputs required to minimize the yield losses. In the dry season, the technological inputs are including supplementary irrigation, droughttolerant seedlings, or switching to cultivate other varieties with lower water requirements.

Indonesian farmers have applied several technologies, either simple or renewable technology, as an adaptation to the changing climate, season, and other phenomena (Apriyana et al., 2017). The farmers have discovered all adaptation efforts that are directly related to water and climate management to be included in planting pattern information in their area. To drain irrigation water from dug wells (boreholes) and rivers, for example, the farmers use pumps. The use of irrigation water sources mainly depends on the planting time and whether it is a normal or a dry climate year. The availability of water in a normal climate year differs from a dry climate year. Farmers switch the source of irrigation water in the dry climate year with a strategy in agricultural cultivation, thus the crop does not experience any stress. Farmers' responses to differing irrigation water sources in the normal and dry climate year in Pati Regency are as follows: in the technical irrigated rice field area, all farmers fully depend on the irrigation water source; in the semitechnical rice field area, all farmers in the normal year utilize the river as the source for $30 \%$ of their irrigation and $70 \%$ in the dry year. In technical irrigation rice fields, planting should be performed 2 to 4 dasarian (10-days period) earlier compared to other agroecosystems.

A study by Nangyal et al., (2016) revealed that at the evaluation level, the effect of transplanting time on yield and its components depends on the ripeness of the rice genotypes. Nangyal et al., (2016) also did climate observation of around $90 \%$ of conditions in Swat Pakistan which was carried out in 2012. The seed distribution was divided into 2 stages, on 9 July 2012 and 24 July 2012. The overall results of this research led us to the conclusion that there is a significant effect of planting dates on yield and its components, also days taken for flowering $100 \%$ of fine-grain rice genotypes. Transplantations from 1-15 July are the most suitable period to get better results from grain rice genotypes. All studied rice genotypes were found to be sensitive to photoperiods.

\section{CONCLUSIONS}

The dominant rice variety planted in the first planting season was IR 64 for about $80 \%$ of the total rice field area, while in the second and third planting seasons was Situ Bagendit variety which was preferred by around $75 \%$ to $80 \%$ of the total farmers. Situ Bagendit variety was preferred in the second and third planting seasons due to its higher tolerance to drought and so higher potential yield. The highest productivity and number of empty grains were attained in planting time June with fertilizer dosage following KATAM recommendation, while the maximum number of filled grain and the average of filled grain were attained in planting time May with fertilizer dosage following 
farmers recommendation. Both results were significantly different from other treatments. The highest gross weight and dry weight of grain, also the highest weight of 1,000 grains of grain were attained planting time June with fertilizer dosage following KATAM recommendation. The productivity of the cultivation at the end of May was around 7.5 tons of milled dry grain/ha while on June was around 8.8 tons/ha. Varieties planted on June 2016 are Situ Bagendit which had a potential yield for above 7.5 tons of milled dry grain/ha, and Ciherang for above 6 tons/ha. The variety recommended to be planted in planting season I is Mekongga and Situ Bagendit in planting season II or III.

\section{ACKNOWLEDGEMENT}

Authors thank to all those who have helped the implementation of assessment activities, including dissemination, verification and validation of integrated KATAM, especially for the Head of BPTP Central Java Region, Head of the Institute of Counseling, Head of the Department of Agriculture Boyolali, and companion extensions.

\section{REFERENCES}

Anggarendra, R., Guritno, C.S., Singh, M., 2016. Use of Climate Information for Rice Farming in Indonesia, in: Kaneko, S., Kawanishi, M. (Eds.), Climate Change Policies and Challenges in Indonesia. Springer Japan, Tokyo, pp. 295-304. https://doi.org/10.1007/978-4-431-559948_13

Apriyana, Y., Sarvina, Y., Dewi, E.R., Pramudia, A., 2017. Farmer adaptation strategy in paddy field affected by climate variability in monsoon regions. Asian J. Agric. 1, 9-16.

Aslam, M., 2016. Agricultural productivity current scenario, constraints and future prospects in Pakistan. Sarhad J. Agric. 32, 289-303.

Badan Penelitian dan Pengembangan Pertanian, 2016. KATAM Terpadu Modern.

BPPP, 2019a. Varietas Unggul [WWW Document]. Kemeterian Pertan. Badan Litbang Pertan. URL http://www.litbang.pertanian.go.id/varietas/12 $0 /$ (accessed 11.9.20).

BPPP, 2019b. Varietas Unggul [WWW Document]. Kemeterian Pertan. Badan Litbang Pertan. URL http://www.litbang.pertanian.go.id/varietas/15 8/ (accessed 12.17.20).

BPS, 2016. Kecamatan Banyudono Dalam Angka 2016. Badan Pusat Statistik Kabupaten Boyolali.

BPS, 2016b. Jumlah Curah Hujan dan Hari Hujan Menurut Bulan di Kabupaten Boyolali Tahun 2016. BPS Kabupaten Boyolali.
Bruinsma, J., 2003. World agriculture: towards 2015/2030: an FAO perspective. Earthscan.

Espe, M.B., Cassman, K.G., Yang, H., Guilpart, N., Grassini, P., Van Wart, J., Anders, M., Beighley, D., Harrell, D., Linscombe, S., 2016. Yield gap analysis of US rice production systems shows opportunities for improvement. Field Crops Res. 196, 276283.

Estiningtyas, W., Rahman, A., 2020. Determinant Factor of Food Farming Vulnerability in Banten Province To Support Climate Change Adaptation. Agromet 34, 129-142.

Fahri, A., Syuryati, S., Yulfida, A., Yusuf, R., 2019. Penerapan Sistem Informasi Kalendar Tanam (SI KATAM) Mendukung Peningkatan Indeks Pertanaman Padi Kabupaten Indragiri Hulu. Din. Pertan. 35, 1-8.

Fudjaja, L., Tenriawaru, A., Diansari, P., Sulili, A., Wirdansyah, A., 2020. Analysis of the relationship of soybean farmers response and income on The Pajale Special Efforts (UPSUS). Presented at the IOP Conference Series: Earth and Environmental Science, IOP Publishing, $\mathrm{p}$. 012046.

Juhandi, D., Sembiring, A., Odang, N.K., 2018. Development of Disadvantaged Districts Based on Pajale (Rice, Corn, and Soybean) in West Sumatera. Presented at the 4th International Conference on Food, Agriculture and Natural Resources (FANRes 2018), Atlantis Press.

Killi, D., Bussotti, F., Raschi, A., Haworth, M., 2017. Adaptation to high temperature mitigates the impact of water deficit during combined heat and drought stress in $\mathrm{C} 3$ sunflower and $\mathrm{C} 4$ maize varieties with contrasting drought tolerance. Physiol. Plant. 159, 130-147. https://doi.org/10.1111/ppl.12490

Koesrini, K., Alwi, M., Saleh, M., 2019. Adaptasi dan Keragaan Hasil Varietas Unggul Padi di Lahan Rawa Wilayah Perbatasan Kalimantan Barat. J. Penelit. Pertan. Tanam. Pangan 3, 53-59.

Koh, H.L., Teh, S.Y., 2020. Climate Change Mitigation and Adaptation: Role of Mangroves in Southeast Asia, in: Leal Filho, W., Azul, A.M., Brandli, L., Özuyar, P.G., Wall, T. (Eds.), Climate Action. Springer International Publishing, Cham, pp. 224-236. https://doi.org/10.1007/978-3-319-958859_107

Lilai, X., Yuanrong, H., Wei, H., 2016. A multidimensional integrated approach to assess flood risks on a coastal city, induced by sealevel rise and storm tides. Environ. Res. Lett. 11, 
$014001 . \quad$ https://doi.org/10.1088/17489326/11/1/014001

Lillo, A., Matteau, J.-P., Kokulan, V., Benalcazar, P., 2019. The Contribution of Wetlands Towards a Sustainable Agriculture in Canada. SSRN. https://dx.doi.org/10.2139/ssrn.3484143

Loboguerrero, A.M., Campbell, B.M., Cooper, P.J., Hansen, J.W., Rosenstock, T., Wollenberg, E., 2019. Food and earth systems: priorities for climate change adaptation and mitigation for agriculture and food systems. Sustainability 11, 1372. https://doi.org/10.3390/su11051372

Mottaleb, K.A., Rejesus, R.M., Murty, M., Mohanty, S., Li, T., 2017. Benefits of the development and dissemination of climate-smart rice: ex ante impact assessment of drought-tolerant rice in South Asia. Mitig. Adapt. Strateg. Glob. Change 22, 879-901. https://doi.org/10.1007/s11027016-9705-0

Mursidi, A., Sari, A., 2017. Management of drought disaster in Indonesia. J. Terap. Manaj. Dan Bisnis 3, 165-171.

Nakano, Y., Tsusaka, T.W., Aida, T., Pede, V.O., 2018. Is farmer-to-farmer extension effective? The impact of training on technology adoption and rice farming productivity in Tanzania. World Dev. 105, 336-351.

Nangyal, H., Shah, A.H., Akhtar, N., 2016. Effect of Different Transplanting Dates on Germplasm Rice Yield and its Yield Components. Am.Eurasian J Agric Env. Sci 16, 571-576.

Perdinan, Boer, R., Kartikasari, K., 2008. Linking Climate Change Adaptation Options for Rice Production and Sustainable Development in Indonesia (Keterkaitan Opsi-opsi Adaptasi Perubahan Iklim Untuk Produksi Beras Nasional Dan Pembanguan Berkelanjutan Di Indonesia). Agromet 22, 94-108. https://doi.org/10.29244/j.agromet.22.2.94108

Satoto, S., Widyastuti, Y., Susanto, U., Mejaya, M.J., 2013. Perbedaan Hasil Padi Antarmusim di Lahan Sawah Irigasi. IPTEK Tanam. Pangan 8, 55-61.

Setiapermas, M.N., Jauhari, S., 2008. Pemanfaatan Sumber Air Pegunungan Untuk Mengantisipasi Kekeringan Pada Musim Kemarau Untuk Tanaman Kubis (to Exploit Mountain Water Resource for Anticipation Drought at Dry Season for Cabbage). Agromet 22, 174-181. https://doi.org/10.29244/j.agromet.22.2.174181

Shrestha, B.M., Chang, S.X., Bork, E.W., Carlyle, C.N., 2018. Enrichment planting and soil amendments enhance carbon sequestration and reduce greenhouse gas emissions in agroforestry systems: A review. Forests 9, 369. https://doi.org/10.3390/f9060369

Srihartanto, E., Widodo, S., 2020. The Potency of the Rice Crop Index Development through Adjustment of Agroclimate and Water Management Situated in Rainfed Field Gunungkidul. Agromet 34, 75-88. https://doi.org/10.29244/j.agromet.34.2.75-88

Sution, S., Sugiarti, T., Hartono, H., Lehar, L., 2019. Pengaruh Dua Musim Tanam Berbeda dan Beberapa Varietas Terhadap Pertumbuhan dan Produktivitas Padi Gogo. AGRIEKSTENSIA J. Penelit. Terap. Bid. Pertan. 18, 24-31.

Thi Nhung, T., Le Vo, P., Van Nghi, V., Quoc Bang, H., 2019. Salt intrusion adaptation measures for sustainable agricultural development under climate change effects: A case of $\mathrm{Ca} M a u$ Peninsula, Vietnam. Clim. Risk Manag. 23, 88100. https://doi.org/10.1016/j.crm.2018.12.002

Thierfelder, C., Chivenge, P., Mupangwa, W., Rosenstock, T.S., Lamanna, C., Eyre, J.X., 2017. How climate-smart is conservation agriculture $(\mathrm{CA})$ ? - its potential to deliver on adaptation, mitigation and productivity on smallholder farms in southern Africa. Food Secur. 9, 537560. https://doi.org/10.1007/s12571-0170665-3

Velasco-Muñoz, J.F., Aznar-Sánchez, J.A., BatllesdelaFuente, A., Fidelibus, M.D., 2019. Rainwater harvesting for agricultural irrigation: An analysis of global research. Water 11, 1320. https://doi.org/10.3390/w11071320

Wang, D., Laza, Ma.R.C., Cassman, K.G., Huang, J., Nie, L., Ling, X., Centeno, G.S., Cui, K., Wang, F., Li, Y., Peng, S., 2016. Temperature explains the yield difference of double-season rice between tropical and subtropical environments. Field Crops Res. 198, 303-311. https://doi.org/10.1016/j.fcr.2016.05.008

Yang, W., Peng, S., Laza, R.C., Visperas, R.M., DionisioSese, M.L., 2008. Yield gap analysis between dry and wet season rice crop grown under highyielding management conditions. Agron. J. 100, 1390-1395.

Yasin, I., Ma'shum, M., 2006. Dampak Variabilitas Iklim Musiman Pada Produksi Padi Sawah Tadah Hujan Di Pulau Lombok (Impact of Interannual Climate Variability on Rainfed Paddy Production in Lombok Island). Agromet 20, 3847.

https://doi.org/10.29244/j.agromet.20.2.38-47 